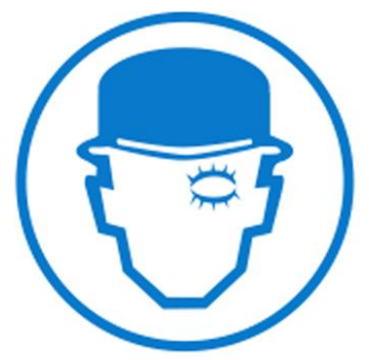

REVISTA TRANSGRESSÕES: CIÊNCIAS CRIMINAIS EM

DEBATE, V.5, N.2, MAIO DE 2017

LARISSA DIAS BARBOSA

GRADUANDA DO CURSO DE LETRAS FRANCÊS PELA UNIVERSIDADE FEDERAL DO RIO GRANDE DO NORTE,

FEMINISTA E POETA.

EMAIL: larissadiasbarbosa@outlook.com

\title{
Vermelho Sangue
}

O vermelho sangue

range, rege, aparece

na janela aberta

por respirar melhor.

E enquanto o Lugar

de cores ternas,

rosto ameno

e aparência forte,

respira com dificuldade

uma onda vermelha

a invade e a devasta.

Quebra os vidros da janela,

Impregna-se na parede,

Derruba os quadros,

Destrói os livros...

Enche-a.

Lugar agora destruído,

Pela onda branca e pegajosa,

Ereta na impunidade

Respira...

não respira...

Respira...

não respira...

Não respira mais. 


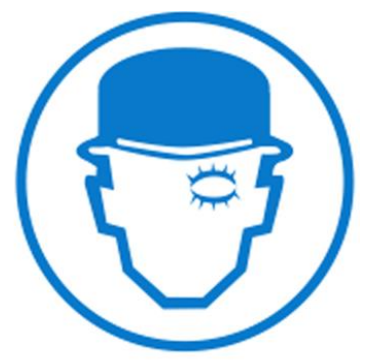

E despida e sem forças,

O Lugar só consegue ouvir

De quem a olha, como

numa expressão de crueldade

natural e sucinta:

Culpada.

Culpada.

Culpada.

Os olhos pesam, os olhos choram

o Lugar destruído, respira com dificuldade.

mas, falar culpada gasta muito ar

a palavra "culpada" repetida 365 vezes

ao ano

SUFOCA.

E ar agora cada vez mais rarefeito,

prende-se ao que é pegajoso

e não encontra o Lugar, que

[Culpada]

Fecha os olhos

[Culpada]

E reza...

[Culpada]

[Culpada]

[Culpada]

Para parar de respirar. 